\title{
PREDICTION OF PROLONGED COURSE OF INFECTIOUS MONONUCLEOSIS IN CHILDREN ON THE BASIS OF STRUCTURAL ORGANIZATION OF LYMPHOCYTES OF BLOOD
}

\author{
Kolesnyk Yana
}

Objectives. The article presents the results of research on the definition of criteria for predicting the adverse course of infectious mononucleosis (IM) in children on the basis of the structural organization of lymphocytes of blood.

Materials and methods. There were 68 children aged three to fifteen years suffering from IM under supervision. The diagnosis of IM was verified by PCR (detection of EBV DNA in the blood) and ELISA (anti-EBV Ig M and Ig G). The biophysical organization of the cytoplasmic membrane of lymphocytes was determined by the method of electron paramagnetic resonance (EPR) of spin probes using the method of additional broadening at microwave parameters $9.39 \mathrm{gHz}$, amplitude of high-frequency modulation 1 gauge, magnetic field scan time $200 \mathrm{sec}$, time constants 0.1 milliseconds (ms). Microviscosity of the intracellular environment of lymphocytes was determined by the mobility parameter of a water-soluble probe (nickel ferricyanide), which easily penetrates into the cytoplasm and in combination with extracellular paramagnetic ions, allows to evaluate the microviscosity of intracellular contents inrelative units (r.u.).

Results. According to the results of observations, it is established that at the stages of manifestation of the disease there are pronounced violations of the biophysical organization of the structure of lymphocytes in the form of a decrease of viscosity and elastic properties of intracellular content and cytoplasmic membrane of lymphocytes. It was characterized by the fact that the average values of the penetration rate of the electron paramagnetic resonance of the spin probe (PR EPR s.p) in patients of both groups were significantly higher than the normative ones. In the group with smooth course, they exceeded the norm by 1.5 times, and in patients with prolonged course by 1.8 times, and the values of the microviscosity of intracellular contents (MIC) were significantly reduced compared to the control - by $22.1 \%$ in patients with a smooth course of the disease and $25.1 \%$ - with a prolonged course of IM.

Conclusions. In patients with prolonged course of IM these disorders were more pronounced than in the smooth course of the disease. In the period of convalescence, the indicators of the biophysical organization of the structure of lymphocytes of patients with a smooth course of IM did not differ from the norm, and in patients with a prolonged course of the disease, their reliable deviation was revealed.

KEY WORDS: children, infectious mononucleosis, structure, lymphocyte, prognosis

\section{INFORMATION ABOUT AUTHORS}

Kolesnyk Yana V., assistant of Department of Children's Infectious Diseases, Kharkiv National Medical University, 160, Geroev Stalingrada, av., Kharkiv, Ukraine, 61000, e-mail: yanakolesnik8@ gmail.com, ID ORCID: https://orcid.org/00000003-2984-6563

\section{INTRODUCTION}

The relevance of the problem of infectious mononucleosis (IM) is determined by the high level of infection of the pediatric population with Epstein-Barr virus (EBV), the possibility of developing an unfavorable course of the disease and the formation, in some cases, of prolonged immunosuppression with deficiency of T-cell and phagocytic immunity.

In the available literature, the issues of etiology, pathogenesis, and clinical manifestations of the disease are sufficiently covered [1,2,3]. However, data on early diagnosis of infectious mononucleosis are controversial $[4,5]$. Late diagnosis of active forms of EBV infection, and therefore untimely treatment, can lead to uncontrolled proliferation of B-lymphocytes, which is a causal factor in the malignancy of WEBinfected cells with the development of lymphoproliferative diseases [6].

It is known that the development and course of infectious pathology depends on the structural and functional state of 
lymphocytes [7]. Among the structural and functional systems of the cell, the cytoplasmic membrane, which provides the cell barrier, ion transport, electrical excitability, intercellular communication, intracellular information transfer, plays an important role [8]. Biological membranes are the first to respond to exterior to the cell effects and modification of their structure and properties often underlies the violation of the normal life of the cell, and, as a consequence, in the development of many pathologies, including cancer [9]. Therefore, the study of the structural organization of blood lymphocytes can be a source of development of new ways of diagnosis of variants of the course of various diseases, including IM.

\section{OBJECTIVE}

Prediction of prolonged course of infectious mononucleosis in children on the basis of structural organization of lymphocytes of blood.

\section{MATERIALS AND METHODS}

There were 68 children aged three to fifteen years suffering from IM under supervision. Of the 68 sick children, 56 $(82,4 \%)$ had a moderate form of the disease, and $12(17,6 \%)$ had a severe form. The severity of the disease was established on the basis of clinical manifestations of the disease and the extent of changes in laboratory tests and instrumental data. All children underwent a standard clinical and laboratory-instrumental examination. The diagnosis of IM was verified by PCR (detection of EBV DNA in the blood) and ELISA (anti-EBV Ig $\mathrm{M}$ and $\mathrm{Ig} \mathrm{G}$ ). In 59 children $(86,8 \%)$, the IM proceeded acutely, smoothly (first group), in $9(13,2 \%)$ it was unfavorable (prolonged course) - the second group. The groups were compared by age, gender, disease severity and other parameters. All children received treatment according to approved protocols (Order of the Ministry of Health of Ukraine No. 354 of 09.07.2004). The biophysical organization of the cytoplasmic membrane of lymphocytes was determined by the method of electron paramagnetic resonance (EPR) of spin probes using the method of additional broadening at microwave parameters $9.39 \mathrm{gHz}$, amplitude of highfrequency modulation 1 gauge, magnetic field scan time $200 \mathrm{sec}$, time constants 0.1 milliseconds (ms). Microviscosity of the intracellular environment of lymphocytes was determined by the mobility parameter of a water-soluble probe (nickel ferricyanide), which easily penetrates into the cytoplasm and in combination with extracellular paramagnetic ions, allows to evaluate the microviscosity of intracellular contents inrelative units (r.u.).

The results of similar studies of postgraduate students of the Department of Department of Children's Infectious Diseases of Kharkiv National Medical University were taken as a control group (Anenkova I. Yu., 2011).

The mathematical and statistical processing of the obtained data was carried out using the standard package of the program «Statistica».

When processing the results of the study, we calculated the arithmetic mean of the series (M), the mean square deviation $(\sigma)$, the error of the arithmetic mean of the series $(m)$. The probability of differences between the averages was determined using the Student's t test (t), and the relationship between the obtained parameters was estimated on the basis of the correlation coefficient (r) and the error probability (p).

\section{RESULTS AND DISCUSSION}

The study of the structural and functional state of the cytoplasmic membrane of lymphocytes showed that the average values of the penetration rate of the electron paramagnetic resonance of the spin probe (PR EPR s.p) in patients of both groups were significantly higher than the normative ones. In the group with smooth course they exceeded the norm by 1.5 times ( $\mathrm{p}<0.001$ ), and in patients with prolonged course by $1 / 8$ times $(p<0.001)$. Highly significant differences were also found between groups of patients. In this case, the value of the PR EPR s.p. in patients with prolonged course by $15.8 \%$ ( $p<0.001$ ) exceeded those in patients with smooth course of IM (tab. 1). 
Distribution of patients in groups according to the values of structural and functional state of lymphocytes

\begin{tabular}{|c|c|c|c|c|c|c|}
\hline \multirow[t]{2}{*}{ Indicators } & \multirow[t]{2}{*}{$\begin{array}{l}\text { Grades of the } \\
\text { indicator }\end{array}$} & \multicolumn{2}{|c|}{$\begin{array}{c}\text { Smooth course } \\
\mathbf{n}=\mathbf{3 7}\end{array}$} & \multicolumn{2}{|c|}{$\begin{array}{l}\text { Prolonged course } \\
\quad \mathbf{n}=\mathbf{3 1} \\
\end{array}$} & \multirow[t]{2}{*}{$\mathbf{P}$} \\
\hline & & abs & $\%$ & abs & $\%$ & \\
\hline \multirow{4}{*}{$\begin{array}{l}\text { PR EPR } \\
\text { s.p.,r.u. }\end{array}$} & $<0,37$ & 8 & 21,6 & 0 & 0 & $<0,001$ \\
\hline & $0,38-0,39$ & 23 & 62,1 & 10 & 32,3 & $<0,001$ \\
\hline & $0,40-0,47$ & 6 & 16,2 & 13 & 41,9 & $<0,001$ \\
\hline & $>0,48$ & 0 & 0 & 8 & 25,8 & $<0,001$ \\
\hline \multicolumn{2}{|c|}{$\mathrm{M} \pm \mathrm{m}$} & \multicolumn{2}{|c|}{$0,38 \pm 0,01 * * *$} & \multicolumn{2}{|c|}{$0,44 \pm 0,011 * * * ; \circ \circ$} & \\
\hline \multicolumn{2}{|c|}{ Control, $\mathrm{n}=23$} & \multicolumn{5}{|c|}{$0,25 \pm 0,011$} \\
\hline \multirow{3}{*}{ MIC, r.u. } & $<1,70$ & 1 & 2,7 & 19 & 61,3 & $<0,001$ \\
\hline & $1,71-1,80$ & 20 & 54,1 & 11 & 35,5 & $>0,05$ \\
\hline & $>1,81$ & 16 & 43,2 & 1 & 3,2 & $<0,05$ \\
\hline \multicolumn{2}{|c|}{$\mathrm{M} \pm \mathrm{m}$} & \multicolumn{2}{|c|}{$1,80 \pm 0,05 * * *$} & \multicolumn{2}{|c|}{$1,64 \pm 0,05 * * * ; \circ \circ$} & \\
\hline \multicolumn{2}{|c|}{ Control, $\mathrm{n}=23$} & \multicolumn{4}{|c|}{$2,31 \pm 0,12$} & \\
\hline
\end{tabular}

Notes:

$* * *-p<0,001$ in comparison with the control group;

${ }^{\circ}-\mathrm{p}<0,001$ in comparison with the smooth course.

It should be noted that the value of the PR EPR s.p. $<0.37$ e.p. were specific to patients with a smooth course of IM, as they were diagnosed only among them (21.6\%) and did not occur in the alternative group $(0 \% ; \mathrm{p}$ $<0.001)$. Interval $0.38-0.39$ r.u. was found to be specific for patients with a smooth disease course, as it was 1,9 times more frequent ( $\mathrm{p}$ $<0.001)$ among them (62.1\%) than among patients with a prolonged course $(32.3 \%)$. Conversely, higher values of the index $(0.40$ 0.47 e.p.) were found to be specific for patients with prolonged course of IM, as 2.6 times more often $(\mathrm{p}<0.001)$ were determined in this group (in $41.9 \%$ ) than among patients with a smooth disease course $(16.2 \%)$. And very high values of the index (> 0.48 e.p.) were determined specific for patients with prolonged course, as they were detected in $25.8 \%$ of them and did not occur in the alternative group $(0 \% ; \mathrm{p}<0.001)$.

With regard to the indicator of microviscosity of the intracellular content (MIC) (see tab. 1), its values were significantly reduced compared with the control - by $22.1 \%(\mathrm{p}<0.001)$ in patients with a smooth course of the disease and by 25 . $1 \%(\mathrm{p}<0.001)$ with prolonged course of IM. In addition, in patients with prolonged disease, the values on $9 \%(p<0.001)$ were lower than in the group with a smooth course of disease. Therefore, the interval of the indicator $<1.70$ r.u. appeared relatively specific for patients with prolonged disease and was determined 23 times more often $(\mathrm{p}<0.001)$ in them $(61.3 \%)$ than in the group with smooth disease $(2.7 \%)$. The index range is $1.71-1.80 \mathrm{ppm}$. was nonspecific, as it was diagnosed in approximately equal ( $p>$ 0.05 ) the proportion of patients in both groups, and the interval > 1.81 r.u. was characteristic of patients with a smooth course of IM, as it was found in $43.2 \%$ of them and 14 times less $(3.2 \% ; \mathrm{p}<0.001)$ in the alternative group.

Therefore, in patients of both groups violations of the biophysical organization of the structure of lymphocytes in the form of reduction of their viscosity and elastic properties were established. In patients with prolonged disease, these disorders are more pronounced. The latter allows us to use them to predict the character of the course of IM.

The study of the structural and functional state of the lymphocytes in the period of early convalescence showed that the average values of the PR EPR s.p. at patients with smooth disease did not differ from the norm, and in the group with prolonged course of IM 1.5 times ( $p$ $<0.001)$ exceeded the norm. In addition, in the group with a prolonged course of the disease compared with the smooth course of the disease, the value of PR EPR s.p. $52 \%$ were higher ( $<$ < 0.001) (tab. 2). 
Distribution of patients in groups according to the values of structural and functional state of lymphocytes (an early convalescence period)

\begin{tabular}{|c|c|c|c|c|c|c|}
\hline \multirow[t]{2}{*}{ Indicators } & \multirow{2}{*}{$\begin{array}{l}\text { Grades of the } \\
\text { indicator }\end{array}$} & \multicolumn{2}{|c|}{ Smooth course $n=37$} & \multicolumn{2}{|c|}{ Prolonged course $n=31$} & \multirow[t]{2}{*}{$\mathbf{P}$} \\
\hline & & abs. & $\%$ & abs. & $\%$ & \\
\hline \multirow{4}{*}{$\begin{array}{l}\text { PR EPR } \\
\text { s.p.,r.u. }\end{array}$} & $<0,20$ & 11 & 29,7 & 0 & 0 & $<0,001$ \\
\hline & $0,21-0,31$ & 21 & 56,8 & 3 & 9,7 & $<0,001$ \\
\hline & $0,32-0,40$ & 5 & 13,5 & 19 & 61,3 & $<0,001$ \\
\hline & $>0,41$ & 0 & 0 & 9 & 29,0 & $<0,001$ \\
\hline \multicolumn{2}{|c|}{$\mathrm{M} \pm \mathrm{m}$} & \multicolumn{2}{|c|}{$0,25 \pm 0,01$} & \multicolumn{2}{|c|}{$0,38 \pm 0,011 * * * ;, \circ \circ$} & \\
\hline \multicolumn{2}{|c|}{ Control, $n=23$} & \multicolumn{5}{|c|}{$0,25 \pm 0,011$} \\
\hline \multirow{3}{*}{$\begin{array}{l}\text { MIC, } \\
\text { r.u. }\end{array}$} & $<1,79$ & 2 & 5,4 & 21 & 67,7 & $<0,001$ \\
\hline & $1,80-2,0$ & 3 & 8,1 & 10 & 32,3 & $>0,05$ \\
\hline & $>2,01$ & 32 & 86,5 & 0 & 0 & $<0,001$ \\
\hline \multicolumn{2}{|c|}{$\mathrm{M} \pm \mathrm{m}$} & \multicolumn{2}{|c|}{$2,430 \pm 0,04 * * *$} & \multicolumn{2}{|c|}{$1,78 \pm 0,02 * * * ;, \circ \circ$} & \\
\hline \multicolumn{2}{|c|}{ Контроль, $\mathrm{n}=23$} & \multicolumn{5}{|c|}{$2,31 \pm 0,12$} \\
\hline
\end{tabular}

Notes:

$* * *-\mathrm{p}<0,001$ in comparison with the control group; ${ }^{\circ}-\mathrm{p}<0,001$ in comparison with the smooth course.

It should be noted that the value of the PR EPR s.p. $<0.20$ r.u. were specific to patients with a smooth course of IM, as they were determined in $29.7 \%$ of them and were not detected in the alternative group $(0 \% ; \mathrm{p}$ $<0.001)$. The index range is $0.21-0.31$ r.u. was relatively specific for patients with a smooth disease, as it was diagnosed in $56.8 \%$ of them and only $9.7 \%(\mathrm{p}<0.001)$ in the group with prolonged course. The interval $0.32-0.40$ was relatively specific for patients with prolonged course of IM and was 4.5 times more frequent $(\mathrm{p}<0.001)$ in them than in the group with smooth course of the disease, very high values of the index (> 0.41 r.u.) were determined to be specific for patients with prolonged disease, as they were found only among them (29\%; $\mathrm{p}<0.001$ ).

With regard to the average values of MIC, in patients with a smooth course of the disease in the period of early convalescence they did not differ from the norm $(p>0.05)$, and in patients with prolonged course of IM they were lower (by $23 \% ; \mathrm{p}<0.001$ ) than normative. In addition, in patients with prolonged course, the values of the indicator were significantly lower $(27 \% ; \mathrm{p}<0.001)$ than in patients with smooth disease. Therefore, the index range is $<1.79$ r.u. 12.5 times more often $(p<0.001)$ was found in the group with a prolonged course of the disease, and a slight decrease or normative (> 2.01 r.u.) its value became specific for patients with a smooth course, as it was diagnosed only among them (in $86.5 \%$ ) and was not determined in the alternative group $(0 \% ; \mathrm{p}<0.001)$.

Thus, in the period of convalescence, a greater proportion of patients with a smooth course of IM showed a normalization of the biophysical organization of the structure of lymphocytes, and in patients with a prolonged course of the disease, a decrease of viscosity and elastic properties of intracellular contents and an increase in permeability of membranes were detected. This, in turn, contributes to the dysfunction of the lymphocytic link of immunity and ultimately leads to the prolongation of the disease.

\section{CONCLUSIONS}

So, the study allows us to draw the following conclusions:

- patients with a smooth course of IM in the debut of the disease revealed a violation of the biophysical organization of the structure of lymphocytes in the form of an increase in the values of PR EPR s.p. and decrease MIC, indicating a decrease of viscosity and elastic properties of intracellular content and cytoplasmic membrane of lymphocytes. In patients with prolonged course of IM, these disorders were more pronounced than in the smooth course of the disease, which allows them to be used for prognostic purposes; 
- in the period of convalescence, the indicators of the biophysical organization of the structure of lymphocytes of patients with smooth course of IM did not differ from the norm, and in patients with prolonged course of the disease their deviations were revealed in the form of disturbance of microviscosity of both intracellular environment and cytoplasm. In our view, these disorders lead to prolonged immunosuppression, which may be an important argument in the development of oncohematologic pathology at later stages of the child's life.

\section{REFERENCES}

1. Krasnov, M. V., Stekolshikova, I. A., Borovkova, M. G. ei al. (2015). Infectious mononucleosis in children. Modern problems of science and education, № 2, (chast 1), 63-69 [in Russian

2. Tyunyaeva, N. O., Sofronova, I. V. (2014). Infectious mononucleosis: etiological factors, diagnosis and treatment problems. Journal of new medical technologies, T 21, № 3, 184-189 [in Russian].

3. Drozdova, N. F., Fazylov, V. H. (2018). Infectious mononucleosis caused by Epstein - Barr virus: clinical and pathogenic aspects (review). The bulletin of contemporary clinical medicine, T 11, V 3, 59-65 [in Russian].

4. Kish, P. P., Koval, G. M., Petrov, V. O. et al. (2013). The specific period of mononucleosis in the children's age. Scientific bulletin of uzhhorod university, V2 (47), 139-144 [in Russian].

5. Pikul, K.V., Ilchenko, V. I., Priluckij, K.Yu. et al. (2011). The specific period of mononucleosis in the children's age. World of Medicine and Biology, № 4, 137-141[in Russian].

6. Blohina, E. B. (2003). Rol latentnoj infekcii, vyzvannoj virusom Epshtejna-Barr, v razvitii limfoproliferativnyh zabolevanij. Pediatric Hematology/Oncology and Immunopathology, T. 2, № 3, 6570 [in Russian].

7. Kuznecov, V. I., Morrison, V. V., Lisko, O. B. et al. (2014). Lipids in the structure and functions of biological membranes. Saratov Journal of Medical Scientific Research, № 2, 262-266 [in Russian].

8. Stolbovskaya, O. V., Hajrullin, R. M., Kulikova, T.K. et al. (2013). The investigation of viscoelastic properties of the cytoplasmic membrane of human blood lymphocytes by atomic-force microscopy. Fundamental research, № 4 (chast5), 1149-1152 [in Russian].

9. Sladkova, E. A., Skorkina, M. Yu., Shamraj, E. A. (2018). Mitogenic response of peripheral blood lymphocytes in patients with lymphocytic leukaemia. Journal of medical and biological research, T. 6 , № 2, 165-173 [in Russian].

\section{ПРОГНОЗУВАННЯ ЗАТЯЖНОГО ПЕРЕБІГУ ІНФЕКЦЙНОГО МОНОНУКЛЕОЗУ У ДІТЕЙ НА ПІДСТАВІ СТРУКТУРНОЇ ОРГАНІЗАЦІЇ ЛІМФОЦИТІВ КРОВІ}

\section{Колесник Я. В.}

Мета. У статті представлені результати досліджень 3 визначення критеріїв прогнозування затяжного перебігу інфекційного мононуклеозу (IM) у дітей на підставі структурної організації лімфоцитів крові.

Матеріали та методи. Під наглядом перебувало 68 дітей у віці трьох - п'ятнадцяти років хворих на IM. Діагноз ІМ верифікували методами ПЛР (виявлення ДНК ВЕБ у крові) і ІФА (анти-ВЕБ Ig M i Ig G). Біофізичну організацію цитоплазматичної мембрани лімфоцитів крові визначали методом електронного парамагнітного резонансу (ЕПР) спинових зондів з використанням методики добавочного уширення при параметрах мікрохвильової частоти 9,39 гігагерц, амплітуди високочастотної модуляції 1 гаусс, часу розвертки магнітного поля 200 сек. константи часу 0,1 мілісекунди (мсек). Про мікров'язкість внутрішньоклітинного середовища лімфоцитів судили по параметру рухливості водорозчинного зонда (ферроцианида нікелю), який легко проникає в цитоплазму і в комбінації з позаклітинними парамагнітним іонами, дозволяє оцінювати мікров'язкість внутрішньоклітинного вмісту в відносних одиницях (від. од.).

Результати. За результатами спостережень встановлено, що на етапах маніфестації захворювання відбуваються виражені порушення біофізичної організації структури лімфоцитів у вигляді зниження в'язкоеластичних властивостей як внутрішньоклітинного вмісту так і цитоплазматичної мембрани лімфоцитів. Це характеризувалося тим, що середні значення швидкості проникнення електронного парамагнітного резонансу спинового зонду (ШП ЕПР с.з.) у хворих обох груп виявилися достовірно вище нормативних. У групі з гладким перебігом вони перевищували норму в 1,5 рази, а у хворих із затяжним перебігом в 1,8 разів, а значення показника мікров'язкісті внутрішньоклітинного середовища (MB ВC) виявилися достовірно зниженими порівняно з контролем - на 22,1 \% у хворих з гладким перебігом захворювання і на 25,1 \% - з затяжним перебігом IM. 
Висновки. У хворих із затяжним перебігом IM зазначені порушення були виражені більшою мірою, ніж при гладкому перебігу хвороби. В періоді реконвалесценції показники біофізичної організації структури лімфоцитів хворих з гладким перебігом IM не відрізнялися від нормативу, а у хворих із затяжним перебігом хвороби виявлено достовірне їх відхилення.

КЛЮЧОВІ СЛОВА:діти, інфекційний мононуклеоз, структура, лімфоцит, прогнозування перебігу

\section{ІНФОРМАЦІЯ ПРО АВТОРІВ}

Колесник Яна Володимирівна, асистент кафедри дитячих інфекційних хвороб Харківського національного медичного університету, пр. Героїв Сталінграду, 160, Харків, Україна, 61000, e-mail: yanakolesnik8@gmail.com, ID ORCID: https://orcid.org/0000-0003-2984-6563

\section{ПРОГНОЗИРОВАНИЕ ЗАТЯЖНОГО ТЕЧЕНИЯ ИНФЕКЦИОННОГО МОНОНУКЛЕОЗА У ДЕТЕЙ НА ОСНОВАНИИ СТРУКТУРНОЙ ОРГАНИЗАЦИИ ЛИМФОЦИТОВ КРОВИ}

Колесник Я. В.

Цели. В статье представлены результаты исследований по определению критериев прогнозирования затяжного течения инфекционного мононуклеоза (ИМ) у детей на основании структурной организации лимфоцитов крови.

Материалы и методы.Под наблюдением находилось 68 детей в возрасте трех - пятнадцати лет больных ИМ. Диагноз ИМ верифицировали методами ПЦР (выявление ДНК ВЭБ в крови) и ИФА (антиВЭБ Ig M и Ig G). Биофизическую организацию цитоплазматической мембраны лимфоцитов крови определяли методом электронного парамагнитного резонанса (ЭПР) спиновых зондов с использованием методики добавочного расширения при параметрах микроволновой частоты 9,39 гигагерц, амплитуды высокочастотной модуляции 1 гаусс, времени развертки магнитного поля 200 сек. константы времени 0,1 миллисекунды (мсек). О микровязкости внутриклеточной среды лимфоцитов судили по параметру подвижности водорастворимого зонда (феррицианида никеля), который легко проникает в цитоплазму и в комбинации с внеклеточными парамагнитным ионами, позволяет оценивать микровязкость внутриклеточного содержания в относительных единицах (от. ед.).

Результаты. По результатам наблюдений установлено, что на этапах манифестации заболевания происходят выраженные нарушения биофизической организации структуры лимфоцитов в виде снижения вязкоэластических свойств как внутриклеточного содержания так и цитоплазматической мембраны лимфоцитов. Это характеризовалось тем, что средние значения скорости проникновения электронного парамагнитного резонанса спинового зонда (ШП ЭПР с.з.) у больных обеих групп оказались достоверно выше нормативных. В группе с гладким течением они превышали норму в 1,5 раза, а у больных с затяжным течением - в 1,8 раза, а значение показателя микровязкости внутриклеточного содержимого (MB BC) оказалось достоверно сниженным по сравнению с контролем - на 22,1\% у больных с гладким течением заболевания и на $25,1 \%$ - с затяжным течением ИМ.

Выводы. У больных с затяжным течением ИМ указанные нарушения были выражены в болышей степени, чем при гладком течении болезни. В периоде реконвалесценции показатели биофизической организации структуры лимфоцитов больных с гладким течением ИМ не отличались от норматива, а у больных с затяжным течением болезни выявлено достоверное их отклонение.

КЛЮЧЕВЫЕ СЛОВА: дети, инфекционный мононуклеоз, структура, лимфоцит, прогнозирования течения

\section{ИНФОРМАЦИЯ ОБ АВТОРЕ}

Колесник Яна Владимировна, ассистент кафедры детских инфекционных болезней Харьковского национального медицинского университета, пр. Героев Сталинграда, 160, Харьков, Украина, 61000, e-mail: yanakolesnik8@gmail.com, ID ORCID: https://orcid.org/0000-0003-2984-6563 